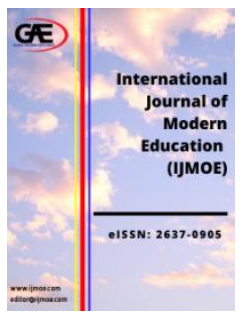

INTERNATIONAL JOURNAL OF

MODERN EDUCATION

(IJMOE)

www.ijmoe.com

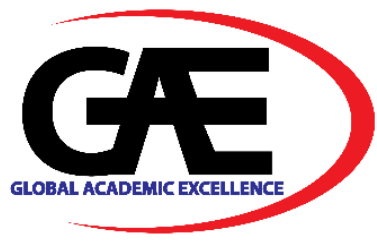

\title{
INTEGRATED AVIATION TRAINING CURRICULUM TRANSFORMATION: THE ROLE OF STRATEGIC LEADERSHIP AND CONTINUOUS QUALITY IMPROVEMENT PRACTICES
}

\author{
Mua'azam Mohamad ${ }^{1 *}$, Shorouk Mohamed Farag Mohamed Aboudahr ${ }^{2}$ \\ 1 School of Education, Universiti Utara Malaysia \\ Email: ibnu.mohamad19@gmail.com \\ 2 School of Education, Universiti Utara Malaysia \\ Email: shrouq.aboudaher@gmail.com \\ * Corresponding Author
}

\section{Article Info:}

\section{Article history:}

Received date: 13.10 .2020

Revised date: 27.10 .2020

Accepted date: 25.01.2021

Published date: 05.03.2021

\section{To cite this document:}

Mohamad, M., \& Aboudahr, S. M. F. M. (2021). Integrated Aviation Training Curriculum Transformation: The Role Of Strategic Leadership And Continuous Quality Improvement Practices. Journal of Modern Education, 3(8), 09-23.

DOI: $10.35631 / \mathrm{JJMOE} .38002$

This work is licensed under $\underline{\mathrm{CC} B Y}$ 4.0

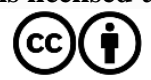

\section{Abstract:}

The integrated aviation training curriculum has been implemented to ensure high-quality aviation personnel training in Malaysia. However, the implementation process seemed to be at a slow pace which requires serious attention to strategic leadership and continuous quality improvement practices, especially in aviation training establishments. Therefore, this paper basically aims to discuss the level of strategic leadership and continuous quality improvement through the implementation of an integrated aviation training curriculum among local aviation academies. Additionally, the relationship between strategic leadership and continuous quality improvement practices will also be highlighted. The research utilized a quantitative approach with a survey design to address the research objectives. The respondents were 60 employees chosen from selected flying training academies using stratified random distribution. Descriptive data were collected through the adapted version of the "Strategic Leadership Questionnaires" and the "Continuous Quality Improvement Climate Survey". Findings indicated that the levels of studied variables were high. Inferential statistics showed that there was a significant positive relationship between strategic leadership and continuous quality improvement practices. Based on the above findings, this paper provides important evidence for the aviation academy management board, national aviation authority, and the aviation community at large with regards to the primary role of strategic leadership and continuous quality improvement practices through the implementation of an integrated aviation training curriculum. 


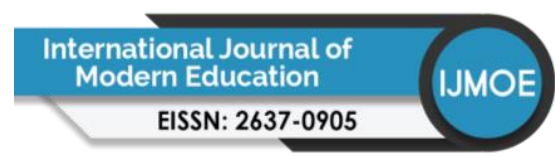

Volume 3 Issue 8 (March 2021) PP. 09-23

DOI: 10.35631/IJMOE.38002

Keywords:

Strategic Leadership, Continuous Quality Improvement Practices, Integrated

Curriculum, Aviation Academy

\section{Introduction}

The 21st century has observed the world internationalization and globalization which give a continuous significant influence on the aviation industry (Button, 2008). In reality, the phenomenon of globalization also has a huge impact on educational and training institutions that demand sustainable strategies in implementing educational transformation towards producing a workforce that is able to compete in the global market (Mariam, Mohammed Sani \& Siti Rahaya, 2009; Mohd Zulfadly, Rohana, Ismail Sabri \& Muhammad Afzamiman, 2011). According to Brown (2019) and Halskov-Jensen (2014), the changes that happen in the aviation industry today are due to the phenomenon of globalization that demands operational transformation and most importantly the adaptation training in aviation operation. In fact, Kucukyilmaz (2019) emphasizes that the transformation process in aviation training organizations should be well planned to optimize and improve performance criteria including cost, quality, flexibility and speed. Thus a positive response to the changes that are taking place is important especially in the effort to realize the policies, goals and vision of training that is undergoing a major overhaul by the new century (Brown, 2019; Button, 2008; Naidoo, Schaap \& Vermeulen, 2014).

In line with the need for quality transformation in aviation training organizations (Kucukyilmaz, 2019), the successful implementation of quality management is subject to the internal components of an organization apart from leadership factors and top management commitment (Fryer, Antony \& Douglas, 2007). A review of the literature proves that there is a lot of descriptive writing emphasizing on staff commitment to quality management practices as a critical element to ensure the successful implementation of quality management (Seetharaman, Sreenivasan \& Boon, 2006; Wardhania et al., 2009). Meanwhile, O'Mahony and Garavan (2012) asserted that the implementation of an effective quality management system is a process of monitoring, continuous improvement and dynamic change. Therefore, continuous quality improvement is a dynamic process of change that requires a high level of motivation and commitment from all members of the organization to realize the management objectives that have been outlined.

Meanwhile, the success of a transformation program to produce holistic human capital depends on the effectiveness of the designed strategic plan. Davies and Davies $(2004,2005,2009)$ see strategy as an important element in the focus of change towards the improvement of educational organizations. Strategic planning is a key aspect in setting the direction of the organization so that change strategies and services can be implemented effectively (Samsuni $\&$ Zakaria, 2005). Therefore, in the aspect of curriculum transformation, the designed strategic plan should not only focus on intellectual elements alone, but should also take into account the aspects of appreciation of knowledge, faith and charity in setting the vision and mission of its implementation (Mohd Zulfadly et al., 2011). However, Dana (2004, 2010) emphasizes that an organization must first be prepared to implement change in order to achieve the objective of continuous improvement. Meanwhile, Santhidran, Chandran and Borromeo (2013) affirm that the willingness to change and commitment to implement change programs among 


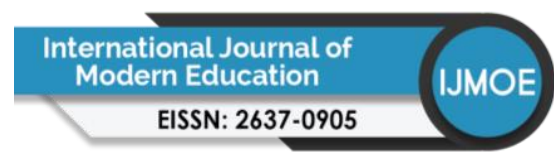

Volume 3 Issue 8 (March 2021) PP. 09-23

DOI: 10.35631/IJMOE.38002

members of the organization towards improving organizational performance is also a direct effect of the role of organizational leadership. This statement reinforces the recommendation by Kotter (1995) who emphasizes leadership strategies as the key in quality improvement model in an organization.

Further, efforts and the need to continuously improve quality to a high level have become increasingly common in all areas of service because it is believed that high quality of service can help organizations remain competitive in the era of globalization (Ehigie \& Akpan, 2004; Juran \& Godfrey, 1999; Khan, 2011). Mohd Khalit (2006) emphasizes that quality services are not empty slogans that are often chanted by all walks of life, but should be a continuous work culture. As a result, awareness of productivity improvement and continuous quality programs, and the desire to implement quality improvement programs in organizations has made management training and quality improvement so popular and rapidly growing (Blackiston, 1996; Hirtz, Murray \& Riordan, 2007). However, there are reports that some organizations still fail to achieve the objective of continuous quality improvement despite the implementation of quality management (Al-Ahmadi \& Roland, 2005; Bhat \& Rajashekar, 2009; Al-Harbi \& Rushami Zien, 2012; Newton, 2002; Yamada, Poltronieri, Gambi \& Gerolamo, 2013). Thus, the practice of continuous and consistent quality improvement is in fact a challenge that needs to be addressed systematically and strategically in the organization to continue to compete in the global market (Gboers, et. al, 1999; Goetsch \& Davis, 2013; Hunter, Ober, Paddock, Hunt \& Levan, 2014; Rashidah, Nurul Huda \& Safura Adeela, 2012).

\section{Problem Statement}

The global aviation industry needs many trained pilots (Brown 2019; The Boeing Company, 2020). However, airlines are more inclined to tighten pilot recruitment requirements rather than focus on quality aspects of pilot trainee training (Baltus, 2012; Naidoo, Schaap \& Vermuelen, 2014; Schaffernak, Moesl, Vorrabel \& Koglbauer, 2020). This decision indirectly resulted in an overload of pilot graduates who failed to obtain a place as pilots in airlines inside and outside the country. Even the global aviation industry is facing the same challenge of supplying skilled manpower able to master the increasingly sophisticated aircraft manufacturing technology and to perform maintenance tasks effectively (Brown, 2019; Chingosho, 2011; Mohamed Elamiri, 2013). In this regard, the Department of Civil Aviation (DCA) Malaysia has taken steps to introduce a new curriculum of more comprehensive theoretical training quality standards to improve the quality of pilot trainees in Malaysia (Jabatan Penerbangan Awam, 2012). However, this change requires the aviation training academy to provide infrastructure and facilities related to teaching and learning aspects to meet the requirements of the quality standards that have been set.

Based on the training needs to improve the quality of pilot graduates, aviation training institutions are required to increase the level of motivation and commitment of the organization's citizens and maintain continuous quality improvement practices to meet the needs of the current aviation industry (Baltus, 2012; Brown, 2019; Kucukyilmaz, 2019). The current scenario is not an obstacle but a new challenge that requires the leadership of a training and education institution to be more consistent and optimistic in practicing more systematic, strategic and quality training quality management practices to continue to compete in the global market (Mariam, Mohammed Sani \& Siti Rahaya, 2009). Therefore, continuous efforts to improve the quality of pilot trainees in Malaysia must involve every layer of citizen in the organization (Jabatan Penerbangan Awam, 2012; Mohd Khalit, 2006). 


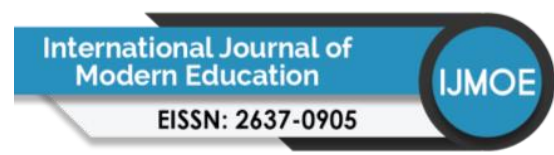

Volume 3 Issue 8 (March 2021) PP. 09-23 DOI: 10.35631/IJMOE.38002

The ongoing quality improvement process assumes and requires a team of collaborative and efficient personnel, together with the organizational leadership to actively use quality approaches in improvement activities and decision-making processes. (Sokovic, Jovanovic, Krivokapic \& Vujovic, 2009). However, the results of previous studies have found that continuous quality improvement programs were ineffective and not fully implemented (Laohavichien, Fredendall \& Cantrell 2011; Alharbi \& Rushami Zien, 2012; Testani \& Ramakrishnan, 2012). Goetsch and Davis (2013) found that top management commitment and vision change for continuous improvement as causal factors that caused quality applications could not be implemented effectively. In addition, there were also human resource factors that contributed to the failure of quality improvement programs in the organization (Bhat \& Rajashekar, 2009; Newton, 2002; Johansson, Fogelberg-dahm \& Wardesten, 2010; Solomonns \& Spross, 2011; Yamada, Poltronieri, Gambi \& Gerolamo, 2013).

\section{Literature Review}

The success of the transformation program requires every member of the organization to always be ready to implement initiatives and improvement efforts. Thus, leadership strategy at the organizational level is a critical aspect to achieve the transformation objectives that have been outlined. Davies and Davies $(2004,2005,2009)$ argue that the aims of strategic leadership should be focused at the organizational level as improvement requires collective behavior change in redesigning the organizational management system. In fact, according to Hairudin (2012), leadership, especially strategic leadership, is identified as an important element in focusing on maintaining readiness for change towards improving educational organizations to produce highly skilled and holistic human capital.

Further, the leadership element has been identified as a major agent of change (Kotter \& Schlesinger, 2008) and is a contributing factor to the sustainability of the implementation of change strategies in the organization (Norshidah, 2011). Ronquillo (2011) emphasizes that the old and outdated leadership style is no longer appropriate, especially in the 21 st century and even needs to be changed to a more strategic, innovative and futuristic leadership style. Thus the elements of leadership and strategic leadership in particular, are widely described as one of the main drivers of effective strategy implementation (Davies \& Davies, 2004; 2006; 2009; Eacott, 2008; Hairudin, 2012; Pearce \& Robinson, 2007; Hrebiniak, 2005). Strategic leaders have an important role to play in every activity of implementing strategic change in the organization (Lahtero \& Kuusilehto-Awale, 2013) while each of the strategic leadership actions positively contributes to the integrity of effective strategy implementation (Hitt, Ireland, Hoskisson, 2007). However, theoretically, strategic leadership is not a new category of leadership but rather a key dimension of leadership activities (Davies \& Davies, 2006) which is able to positively affect performance, innovation, learning and organizational change (Vera \& Crossan, 2004). Therefore, to increase the likelihood of successful change efforts, focus should be given to the ability of the leaders to lead the implementation of strategies and deal with any changes that occur (Judge et. al., 1999) by increasing the element of change readiness in the organization (By, Diefenbach \& Klarner, 2008; Chuzairy \& Mohammad Yusof, 2013).

The continuous implementation of quality improvement programs in the organization aims to increase the productivity of products, services and communications to meet the needs of customers (Dana, 2004; 2010). If applied in the context of aviation training institutions, the practice of continuous quality improvement is expected to enhance student achievement and 


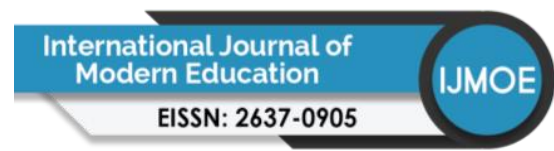

Volume 3 Issue 8 (March 2021) PP. 09-23

DOI: 10.35631/IJMOE.38002

further maintain the excellence and success of the institution. In that perspective, Dana (2010) proposes the use of collaborative approach to improve facilities and improvement processes with emphasis on infrastructure and organizational structure. Prior to that, Donabedian (2005) stated that the concept of structure includes organizational stability, equipment, physical capacity and manpower resources of the organization, including the financial resources required for the provision of a service.

The implementation of continuous quality improvement also emphasizes the involvement and cooperation of all stakeholders in ensuring the higher education agenda can be implemented effectively (Norshah, Adzly, Ramesh \& Mohd Zamri, 2009; Norbahiah, Siti Salasiah, Hafizah $\&$ Wan Mimi Diyana, 2011). The implementation of the continuous quality improvement cycle should be given due attention given its important role in ensuring the quality of students, academic assignments and study programs (Zuraini, Umi Kalthum \& Norizah, 2012). This importance is emphasized by Beer and Nohria (2000), and Smith (2005) that there is a high risk of failure if the readiness of the individual or organization for change is insufficient. Failure to change will slow down improvement efforts that are likely to thwart the achievement targets of the planned improvement program (Beer \& Nohria, 2000). Hence, in the face of the developments and challenges of globalization in the 21st century, the excellence and competitiveness of an organization is highly dependent on the ability to adapt to unexpected changes over time and over and over again (Yavuz Akbulut et al., 2007). In this regard, in the context of continuous improvement of aviation training, the training institution needs to work with the Department of Civil Aviation from the beginning of student recruitment to the final stage of training so that every problem that arises can be analyzed and resolved more effectively.

\section{Research Aims}

This study aimed to examine the relationship between the sustainability of strategic leadership and the practice of continuous quality improvement in aviation training institutions. In addition, predictive factors in strategic leadership to determine the level of implementation of continuous quality improvement practices will also be discussed as important empirical evidence to the citizens of aviation training institutions in general and all stakeholders for the successful transformation plan of integrated aviation training curriculum.

\section{Research Objectives}

In particular the objectives of this study are as follows:

a) Identify the level of strategic leadership practices and the level of continuous quality improvement practices in aviation training institutions.

b) Identify the relationship between strategic leadership practices and continuous quality improvement practices in aviation training institutions.

c) Identify the influence of strategic leadership characteristics on continuous quality improvement practices in aviation training institutions.

\section{Conceptual Framework}

An important aspect identified in driving quality management success is the leadership factor (Bass \& Avolio, 1994). While Goetsch and Davis (2013) state that leadership in quality management is based on the philosophy that continuous improvement efforts for human resources, processes and products will improve quality, value, productivity, services, stock market, organizational sustainability, business development and returns capital. This view is 


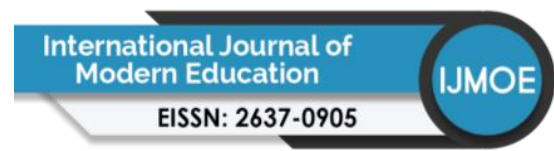

Volume 3 Issue 8 (March 2021) PP. 09-23

DOI: 10.35631/IJMOE.38002

in line with the results of the analysis conducted by Anderson et al. (1995) on Deming management methods (1982). He noted that the key policy in the Deming management method is to create an organizational system that fosters the implementation of quality management practices including customer focus, continuous improvement, and group collaboration, all of which require effective leadership.

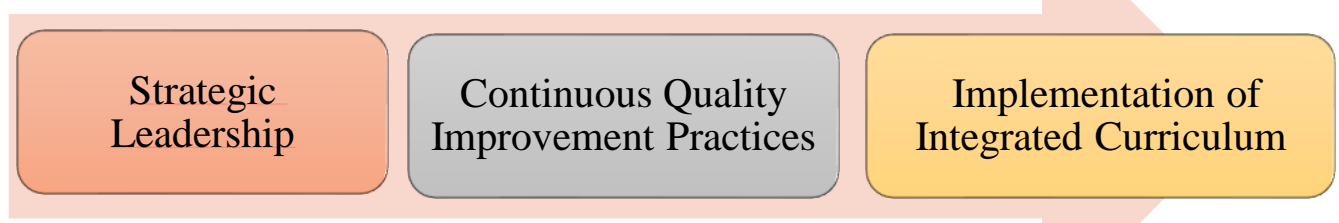

Figure1. Research Conceptual Framework

Dana $(2004,2010)$ emphasizes that an organization must first be prepared to implement the strategy of change in order to achieve the objective of continuous improvement. Manakala Davies (2006), Davies dan Davies (2004, 2005, 2009), and Lahtero and Kuusilehto-Awale (2013) emphasizes the importance of strategic leaders in the implementation of formulated strategies. Thus, based on the conceptual framework in Figure 1, this study aimed to explore and examine the level of strategic leadership practices and continuous quality improvement practices as well as examine the relationship between strategic leadership and continuous quality improvement practices in aviation training institutions.

\section{Research Methodology}

\section{Research Design}

This study is a descriptive study of correlation using a quantitative approach while crosssectional methods were applied to collect data based on the questionnaire answered by the respondents. The population of this study was the citizens of aviation training institutions based in the East Coast of Peninsular Malaysia.

\section{Population and Sampling}

Relatively, the number of aviation vocational education institutions in Malaysia is still too small. During the study, there were only four academies that were active in recruiting trainees. Accordingly, a total of 70 questionnaires were distributed and administered to respondents in all four-academy operation centers who were undergoing active flight training transformation programs. Samples were selected using stratified random sampling from three departments namely the Department of Aviation Training, the Department of Engineering and the Department of Engineering Training who are directly and indirectly involved in aviation training. However, after screening, only 60 questionnaires were selected for analysis. According to Creswell $(2012 ; 2014)$, a sample size over 30 is suitable for most correlation and comparative studies. In terms of gender, the selected sample included $49(81.7 \%)$ male respondents and $11(18.3 \%)$ female respondents. While for the category of vocation, $39(65 \%)$ respondents were executive staff (e.g. coaches, engineers and managers) and 21 (35\%) respondents were from the non-executive category (e.g. Administrative Assistants and Operations Assistants).

Copyright $\odot$ GLOBAL ACADEMIC EXCELLENCE (M) SDN BHD - All rights reserved 


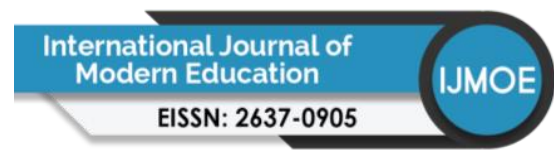

Volume 3 Issue 8 (March 2021) PP. 09-23 DOI: 10.35631/IJMOE.38002

\section{Research Instruments}

The research instrument used was constructed based on two main questionnaires. The level of strategic leadership practice was measured using a strategic leadership questionnaire developed by Hairuddin (2012) based on Davies and Davies strategic leadership model (2004). The measurement focus was based on two groups of key characteristics of a leader's strategic capability including organizational strategic capability and individual strategic capability. While the practice of continuous quality improvement was measured using the Continuous Quality Improvement Climate Survey questionnaire (Dana, 2010). A 7-point Likert scale was used in both questionnaires to increase reliability and reduce errors during data collection (Vagias, 2006). Item reliability analysis was conducted and the Cronbach's alpha coefficient values for both instruments were .98 and .95 respectively. Both parts showed very high reliability values.

\section{Data Analisis}

Data obtained through questionnaires were analyzed using Statistical Package for the Social Science (SPSS) version 20.0. Statistical data analysis using this software can produce accurate calculations (Field, 2009; Pallant, 2013). Descriptive statistical analysis such as mean, frequency and percentage was also conducted to measure the level of strategic leadership practices and continuous quality improvement practices. The mean score interpretation of the data was adapted from Fauzi, Jamal and Mohd Saifoul (2014) which were categorized into three groups based on Likert scale for example low (1.00 to 2.99), medium (3.00 to 4.99) and high (5.00 to 7.00). While inference statistics such as Pearson correlation test and stepwise multiple regression analysis was used to see the relationship and influence between the two study variables. The interpretation of the coefficients $r=0$ to $r=1$ whether positive or negative was based on the scale proposed by Davis (1971).

\section{Findings}

\section{Level of Strategic Leadership Practices}

Measurement of the level of strategic leadership practices was carried out through 32 items of questionnaires. The mean score for the strategic leadership practice variable was 5.22 (SD = .84). This analysis showed that respondents have a perception that the level of strategic leadership practices in their organization as a whole was at a high level. The highest level of strategic leadership practices based on dimensions was the individual strategic ability of the leader $(\mathrm{M}=5.28, \mathrm{SD}=.85)$ followed by the strategic ability of the leader organization $(\mathrm{M}=$ $5.18, \mathrm{SD}=.86)$. The findings of the study also showed that the mean value for all respondents which was 60 people $(100 \%)$ viewed that the strategic leadership practices in their academy were at a high level. The findings also showed that $68.3 \%$ of respondents stated that leadership practices in their organization were at a high level while $30.0 \%$ of respondents' evaluation was at a moderate level. In contrast, one respondent (1.7\%) stated that the level of strategic leadership practices of their organizational leaders was at a low level. Overall it can be concluded that the level of strategic leadership practices among the leaders of aviation training institutions was at a high level. 


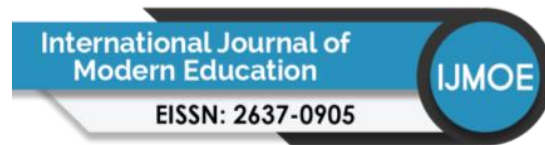

Volume 3 Issue 8 (March 2021) PP. 09-23

DOI: 10.35631/IJMOE.38002

Table 1: Distribution of Mean Scores of Strategic Leadership Practice Variables

\begin{tabular}{lccc}
\hline Descriptive & \multicolumn{3}{c}{ Variables } \\
\cline { 2 - 4 } Statistics & Strategic Leadership & $\begin{array}{c}\text { Organizational } \\
\text { Strategic Capability }\end{array}$ & $\begin{array}{c}\text { Individual Strategic } \\
\text { Capability }\end{array}$ \\
\hline Mean & 5.22 & 5.18 & 5.28 \\
Standard & .84 & .86 & .85 \\
$\begin{array}{l}\text { Deviation } \\
\text { Interpretation }\end{array}$ & High & High & High \\
\hline
\end{tabular}

\section{Continuous Quality Improvement Practices}

Measurement of the level of continuous quality improvement practices was conducted through 25 questionnaire items. The mean score for the variable of continuous quality improvement practices was $5.27(\mathrm{SD}=.79)$. This analysis showed that respondents have a perception that the level of continuous quality improvement practices of their organization as a whole was at a high level. The highest levels of continuous quality improvement practices based on dimensions were data usage practices $(\mathrm{M}=5.44, \mathrm{SD}=.82)$ followed by quality understanding $(\mathrm{M}=5.28, \mathrm{SD}=.98)$, quality focus $(\mathrm{M}=5.26, \mathrm{SD}=.79)$, process understanding $(\mathrm{M}=5.25$, $\mathrm{SD}=1.03)$, and quality leadership recorded the lowest scores $(\mathrm{M}=5.13, \mathrm{SD}=.96)$. The findings also showed that from the total respondents of 60 people, $27.8 \%$ viewed that the continuous quality improvement practices in their academy were at moderate level, whereas $72.2 \%$ viewed as high.

Table 2: Distribution of Mean Scores of Respondents' Continuous Quality Improvement Practices

\begin{tabular}{lcccccc}
\hline & \multicolumn{5}{c}{ Variables } \\
\cline { 2 - 7 } $\begin{array}{l}\text { Descriptiv } \\
\text { e Statistics }\end{array}$ & $\begin{array}{c}\text { Continuous } \\
\text { Quality } \\
\text { Improvement } \\
\text { s }\end{array}$ & $\begin{array}{c}\text { Quality } \\
\text { Focus }\end{array}$ & $\begin{array}{c}\text { Process } \\
\text { Understanding }\end{array}$ & $\begin{array}{c}\text { Data } \\
\text { Usage }\end{array}$ & $\begin{array}{c}\text { Quality } \\
\text { Understanding }\end{array}$ & $\begin{array}{c}\text { Quality } \\
\text { Leadership }\end{array}$ \\
\hline Mean & 5.27 & 5.26 & 5.25 & 5.44 & 5.28 & 5.13 \\
Standard & .79 & .79 & 1.03 & .82 & .98 & .96 \\
$\begin{array}{l}\text { Deviation } \\
\begin{array}{l}\text { Interpretat } \\
\text { ion }\end{array}\end{array}$ & High & High & High & High & High & High \\
\hline
\end{tabular}

Relationship between Strategic Leadership and Continuous Quality Improvement Practices Pearson correlation test analysis was used to test and identify the significant relationship between strategic leadership and continuous quality improvement practices among aviation training institutions. Based on Table 3, the results of the Pearson correlation test showed that strategic leadership practices have a statistically significant positive relationship $(r=.85, p$ $<.01$ ) with continuous quality improvement practices. Pearson correlation tests were also used to examine the strength of the relationship between the dimensions of strategic leadership (Davies \& Davies, 2004) and the dimensions of continuous quality improvement practices (Dana, 2010). Findings showed that organizational capability components $(r=0.82, p<0.01)$ and individual capability components $(\mathrm{r}=0.84, \mathrm{p}<0.01)$ have a significant and strong relationship with continuous quality improvement practices in aviation training academies. In addition, strategic leadership variables have a significant positive relationship with the five dimensions of continuous quality improvement practices namely quality focus $(\mathrm{r}=0.81, \mathrm{p}<$ Copyright $\odot$ GLOBAL ACADEMIC EXCELLENCE (M) SDN BHD - All rights reserved 


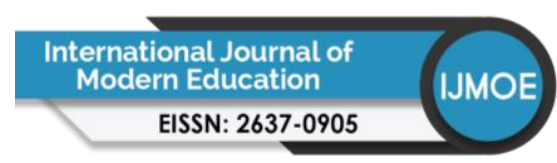

Volume 3 Issue 8 (March 2021) PP. 09-23 DOI: 10.35631/IJMOE.38002

$0.01)$, process understanding $(\mathrm{r}=0.78, \mathrm{p}<0.01)$, data usage $(\mathrm{r}=0.71, \mathrm{p}<0.01)$, quality understanding $(r=0.61, p<0.01)$ and quality leadership $(r=0.79, p<0.01)$.

Table 3: Correlation between Strategic Leadership and Continuous Quality Improvement Practices

\begin{tabular}{lcccccc}
\hline Dimensions & $\begin{array}{l}\text { Continuous } \\
\text { Quality } \\
\text { Improvement } \\
\text { Practices }\end{array}$ & $\begin{array}{l}\text { Quality } \\
\text { Focus }\end{array}$ & $\begin{array}{l}\text { Process } \\
\text { Understanding }\end{array}$ & $\begin{array}{l}\text { Data } \\
\text { Usage }\end{array}$ & $\begin{array}{l}\text { Quality } \\
\text { Understanding }\end{array}$ & $\begin{array}{c}\text { Quality } \\
\text { Leadership }\end{array}$ \\
\hline $\begin{array}{l}\text { Strategic } \\
\text { Leadership }\end{array}$ & $.85^{* *}$ & $.81^{* *}$ & $.78^{* *}$ & $.71^{* *}$ & $.61^{* *}$ & $.79^{* *}$ \\
$\begin{array}{l}\text { Organizational } \\
\text { Capability }\end{array}$ & $.82^{* *}$ & $.80^{* *}$ & $.75^{* *}$ & $.67^{* *}$ & $.59^{* *}$ & $.78^{* *}$ \\
$\begin{array}{l}\text { Individual } \\
\text { Capability }\end{array}$ & $.84^{* *}$ & $.79^{* *}$ & $.78^{* *}$ & $.74^{* *}$ & $.60^{* *}$ & $.76^{* *}$ \\
\hline$* * p<.01(2$ tailed) & & & & & &
\end{tabular}

\section{Predictor Dimensions Level of Continuous Quality Improvement Practices}

Stepwise multiple regression analysis was conducted to determine whether the scores for both groups of strategic leadership characteristics; organizational strategic capability and individual strategic capability were needed to predict the level of continuous quality improvement practices in aviation training institutions. The first stage analysis found that the individual strategic capability clusters were included in the regression equation and were found to have a significant positive relationship with the level of continuous quality improvement practices tested $[\mathrm{F}(1,58)=136.34, \mathrm{p}<.000]$. The double correlation coefficient was .702 , which explained that there was a change in the variance of continuous quality improvement practices of $70.2 \%$ contributed by the individual strategic capability group. However, the organizational strategic capability group was not included in the second stage analysis $(t=1.93, p>.05)$. Accordingly, the results of the analysis showed that only the group of individual strategic capability was a significant predictor factor to determine the level of continuous quality improvement practices in aviation training institutions.

Table 4: Stepwise Multiple Regression Analysis of Individual Leader Ability Strategies as Predictors of Continuous Quality Improvement Practices

\begin{tabular}{|c|c|c|c|c|c|}
\hline Variables & B & Beta & $\begin{array}{c}\text { Standard Error } \\
\text { Beta }\end{array}$ & $\mathrm{t}$ & $\mathrm{p}$ \\
\hline \multicolumn{6}{|c|}{ Model $1 \mathrm{~F}(1,58)=136.34, p=.000 ; \mathrm{R}^{2}=.702$} \\
\hline $\begin{array}{l}\text { Individual Strategic } \\
\text { Capability }\end{array}$ & .801 & .838 & .069 & 11.677 & .000 \\
\hline
\end{tabular}

\section{Discussion}

The descriptive statistical data analysis found that the level of strategic leadership and continuous quality improvement practices in aviation training academies as a whole was at a high level. The findings of the study proved the existence of a positive relationship between the level of readiness of organizational change with continuous quality improvement practices (Santhidran, Chandran \& Borromeo, 2013; Testani \& Ramakrishnan, 2012; Yavuz Akbulut, et. al, 2007; Ovretveit, 2005). Thus a high level of strategic leadership practice will be able to increase the commitment to change and improvement initiatives in the organization (Bass \& 


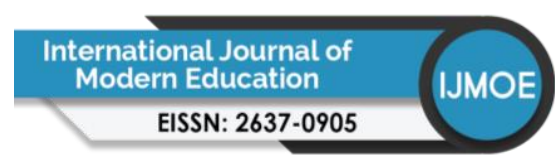

Volume 3 Issue 8 (March 2021) PP. 09-23 DOI: 10.35631/IJMOE.38002

Avolio, 1994; Dana, 2004; 2010; Lyons, Swindler \& Offner, 2009; Testani \& Ramakrishnan, 2012; Victorian Quality Council, 2006). In this regard, quality management has been used as a strategy to achieve a high level of excellence and the ability to remain highly competitive (Khan, 2011; Mariam, Mohammed Sani \& Siti Rahayah, 2009).

The findings of this study are also found to be in line with the findings of Rashidah, Nur Huda, Safura Adeela and Azizah (2012) who found that the organization in which a culture of quality improvement will always be ready to take any action to implement continuous quality improvement. Therefore, efforts to create a strong quality culture in the organization which is an important foundation for the implementation of quality management principles should be given due focus and emphasis on every layer of management and operations of an organization.

Furthermore, the importance of the level of strategic leadership in influencing the practice of continuous quality improvement has been proven based on the results of the study. Increase in the level of strategic leadership (Davies \& Davies, 2004) was found to be able to improve the practice of continuous quality improvement (Dana, 2004; 2010) especially from the aspect of data usage, quality understanding and quality focus. This significant positive relationship is found to be in line with the Victorian Quality Council statement (2006). Organizations that preserve strategic leadership practices will form a high climate of continuous quality improvement, while low levels of strategic leadership practices will exhibit low levels of continuous quality improvement practices.

\section{Conclusion}

The results showed that leadership practices among academics are important to ensure readiness to face any changes that will occur in the organization. These findings implied that the top management of the academy needs to plan and design programs and initiatives continuously to maintain the level of quality and standard of the aviation training curriculum. Emphasis should be given to citizens among executive staff to always communicate effectively with staff at the non-executive level to improve the sustainability of leadership strategies more effectively. An analysis of the dimensions of continuous quality improvement practices found that overall, the dimensions of data usage were more frequently practiced followed by quality understanding quality and quality focus. However, the level of practice at every level was found to be non-uniform which requires appropriate intervention to ensure that the quality standards of training are preserved and maintained at a high level. In this context, the management of the academy needs to emphasize the aspect of quality understanding by designing and planning more quality improvement programs to increase the people's understanding of the quality aspect, especially quality in the aviation industry.

This study as a whole has successfully proven that there is a significant relationship between strategic leadership and the practice of continuous quality improvement. The dimensions of individual strategic capability of the leaders were identified to have a strong influence on the practice of continuous quality improvement in aviation training institutions. From the body of knowledge perspective, the findings of this study are expected to contribute meaningful new information towards producing high quality and effective aviation training academies. Furthermore, this study can also be used as a source of information and reference for those who will continue the struggle as researchers in the field of education and training management in the future. 


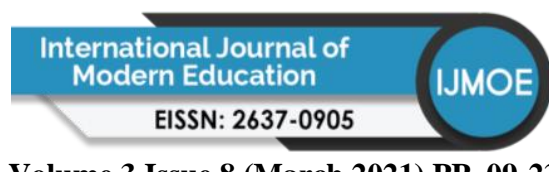

Volume 3 Issue 8 (March 2021) PP. 09-23 DOI: 10.35631/IJMOE.38002

\section{References}

Al-Ahmadi, H., \& Roland, M. (2005). Quality of primary health care in Saudi Arabia: a comprehensive review. International Journal for Quality in Health Care, 17(4), 331 346.

Al-Harbi, M., \& Rushaimi ZienYusoff. (2012). Leadership styles and their relationship with quality management practices in public hospitals in Saudi Arabia. International Journal of Economics and Management Sciences, 1(10), 59-67.

Atallah Basheer Alnaweigah. (2013). Total quality management role in organizational change and development - Case study: Taif University. International Journal of Business Administration, 4(4), 55 - 67.

Bass, B.M., \& Avolio, B.J. (1994). Improving organizational effectiveness through transformational leadership. Sage, Thousand Oaks.

Baltus, R. (2012). The future of pilot training: Quality of training, funding and jobs. Paper presented in European Airline Training Symposium on 6-7 November 2012, Berlin, Jerman. Dimuat turun daripada http://halldale.com/eats-2012/proceedings.

Beer, M., \& Nohria, N. (2000). Breaking the code of change. Boston: Harvard Business School Press.

Bhat, K. S. \& Rajashekar, J. (2009). An empirical study of barriers to TQM implementation in Indian industries. The TQM Magazine, 21(3), $261-272$.

Blackiston, G. H. (1996). A barometer of trends in quality management. National Productivity Review, 16, $15-23$.

By, R.T., Diefenbach, T., \& Klarner, P. (2008). Getting organizational change right in public services: The case of European higher education. Journal of Change Management, $8(1), 21-35$.

Brown, L. (2019). Augmented reality in international pilot training to meet training demands. Instructional Development Grants. 1. Retrieved from https://scholarworks.wmich.edu/instructional-development-grants/1

The Boeing Company (2020). Boeing Pilot \& Technician Outlook 2020-2039. Available online: https://www.boeing.com/commercial/market/pilot-technician outlook/ (accessed on 18 January 2021).

Button, K. (2008). The impacts of globalisation on international air transport activity: Past trends and future perspectives. Global Forum on Transport and Environment in a Globalising World, 10-12 November 2008, Guadalajara, Mexico.

Chingosho, E. (2011). Teks ucapan perasmian $3^{\text {rd }}$ Pan-African Aviation Training Coordination Conference, Cape Town, South Africa 27-29 July 2011.

Chuzairy Hanri, \& Mohammad Yusof Arshad. (2013). Ke arah pendidikan yang lebih berkualiti: Pengamalan pengajaran guru kimia dalam menggalakkan kreativiti. Prosiding 2nd International Seminar on Quality and Affordable Education.

Dana, B. (2004). Continuous quality improvement climate survey process and tool. American Health Care Association.

Dana, B. (2010). Continuous quality improvement climate survey process and tool. American Health Care Association.

Davis, J. A. (1971). Elementary survey analysis. New Jersey: Prentice Hall.

Davies, B. (2004). Developing the strategically focused school. School Leadership \& Management, 24(1), 11-27.

Davies, B. (2006). Leading the strategically focused School for success and sustainability. London:Sage. 


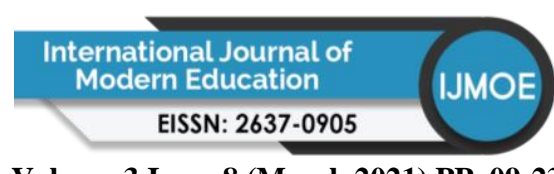

Volume 3 Issue 8 (March 2021) PP. 09-23

DOI: 10.35631/IJMOE.38002

Davies, B. J. \& Davies, B. (2004). Strategic leadership, school leadership and management. Formerly School Organisation, 24(1), 29-38.

Davies, B. \& Davies, B.J. (2005), Strategic leadership. Dalam B. Davies (ed.), The Essentials of School Leadership. London: Paul Chapman.

Davies, B. \& Davies, B.J. (2009), Strategic leadership. Dalam B. Davies (2nd ed.), The Essentials of School Leadership. London: Paul Chapman.

Deming, W.E. (1982). Quality productivity and competitive position. Massachusetts Institute of Technology, Center for Advanced Engineering Study, Cambridge, MA.

Donabedian, A. (2005). Evaluating the quality of medical care. The Milbank Quarterly, 83(4), $691-729$.

Eacott, S. (2008). Strategy and educational leadership: In search of unity. Journal of Educational Administration, 46(3), 353-375.

Ehigie, B. O., \& Akpan, R. C. (2004). Roles of perceived leadership styles and rewards in the practice of total quality management. Leadership \& Organization Development Journal, 25(1),24-40.

Fauzi Hussin, Jamal Ali \& Mohd Saifoul Zamzuri Noor. (2014). Kaedah penyelidikan \& analisis data SPSS. Universiti Utara Malaysia Press, Sintok.

Finkelstein, S., Hambrick, D. C., \& Cannella, Jr., A. A. (2009). Strategic leadership: Theory and research on executives, top management teams, and boards. New York, NY: Oxford University Press.

Field, A. (2009). Discovering statistics using SPSS. ( $3^{\text {rd }}$ ed). London: SAGE publications.

Fryer K., Antony J., \& Douglas A. (2007). Critical success factors of continuous improvement in the public sector: a literature review and some key findings. The TQM Magazine, 19 (5), 497-517.

Geboers, H., Grol, R., Bosch, W., Hoogen, H., Mokkink, H., Montfort, P. \& Oltheten, H. (1999). A model for continuous quality improvement in small scale practices. Quality in Health Care. 8, $43-48$.

Gilley, A., Dixon, P., \& Gilley, J. W. (2008). Characteristic of leadership effectiveness: Implementing change and driving innovation in organizations. Human Resource Development Quarterly, 19(2), 153-170.

Grandy, G. (2013). An exploratory study of strategic leadership in churches. Leadership \& Organization Development Journal, 34 Iss: (7), 616 - 638.

Goetsch, D. L., \& Davis, S. B. (2013). Quality management for organizational excellence: Introduction to total quality. Pearson.

Hairuddin Mohd Ali. (2012). The quest for strategic Malaysian Quality National Primary School Leaders. International Journal of Educational Management, 26(1), 83 - 98.

Halskov-Jensen, A. (2014). Five ways to improve training. ICAO training report, 4(2), $4-7$.

Hirtz, P. D., Murray, S. L., \& Riordan, C. A. (2007). The effects of leadership on quality. Engineering Management Journal, 19(1), 22 - 27.

Hitt, M. A., Ireland, R. D. \& Hoskisson, R. E. (2007). Strategic Management: Competitiveness and Globalization (7th Ed), Cincinnati: South-Western / Thomson Learning.

Hitt, M. A., Haynes, K. T., \& Serpa, R. (2010). Strategic leadership in the twenty-first century. Business Horizons, 53(5), 437-453.

Hrebiniak, L.G. (2005). Making Strategy Work: Leading Effective Execution and Change. Upper Saddle River, NJ: Wharton School Publishing.

Hunter, S. B., Ober, A. J., Paddock, S. M., Hunt, P. E. \& Levan, D. (2014). Continuous quality improvement (CQI) in addiction treatment settings: design and intervention 


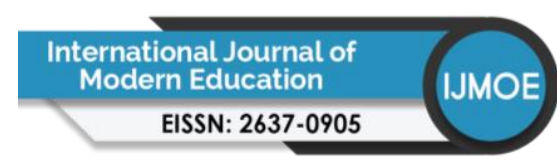

Volume 3 Issue 8 (March 2021) PP. 09-23

DOI: 10.35631/IJMOE.38002

protocol of a group randomized pilot study. Addiction Science \& Clinical Practice, 9(4), $1-11$.

Ireland, R. D., \& Hitt, M. A. (2005). Achieving and mantaining strategic competitiveness in the 21st century: The role of strategic leadership. Academy of Management Executive Journal, 19(4), 63.

Jabatan Penerbangan Awam. (2012). Ground examination: Migration to EASA Part-FCL from JAR-FCL examination for DCA Malaysia flight crew licensing (FCL) requirements. Aeronautical Information Circular 05/2012, Putrajaya.

Johansson, B., Fogelberg-dahm, M, \& Wadensten, B. (2010). Evidence-based practice: the importance of education and leadership. Journal of Nursing Management, 18, 70-77.

Judge, T., Thoresen, C., Pucik, V., \& Welbourne, T. (1999). Managerial coping with organizational change: a dispositional perspective. Journal of Applied Psychology, 84(1), 107-122.

Juran, J. M. \& Godfrey, A. B. (1999). Juran's Quality Handbook. McGraw Hill, New York.

Khan, M.A. (2011). Total quality management and organizational performance-moderating role of managerial competencies. International Journal of Academic Research, 3(5), 453-458.

Kementerian Pengangkutan Malaysia. (2012). Permohonan tubuh sekolah penerbangan baru dibekukan. Portal Rasmi Kementerian Pengangkutan Malaysia. Dimuat turun daripada http://www.mot.gov.my/CurrentNews/Pages/Permohonan

\%20Tubuh\%20Sekolah\%20Penerbangan\%20Baru\%20Dibekukan.aspx

Kotter, J.P. (1995). Leading change: Why transformation efforts fail. Harvard Business Review, March-April, 59-67.

Kotter, J. P., \& Schlesinger, L. A. (2008, July - August). Choosing strategies for change. Harvard Business Review. 130 - 139.

Kucukyilmaz, A. (2019). Transformation process risk management to sustainable corporate performance and quality management: developing flowcharts for approved training organization. Aircraft Engineering and Aerospace Technology, 92(2), 201-212.

Lahtero, T. J., \& Kuusilehto-Awale, L. (2013). Realisation of strategic leadership in leadership teams' work as experienced by the leadership team members of basic education schools. School Leadership \& Management: Formerly School Organisation, 33(5), 457-472.

Laohavichien, T., Fredendall, L. D.,\& Cantrell, R. S. (2011). Leadership and quality management practices in Thailand. International Journal of Operations and Production Management, 31(10), 1048 - 1070.

Lyons, J. B., Swindler, S. D., \& Offner, A. (2009). The impact of leadership on changereadiness in the US Military. Journal of Change Management, 9(4), 459-475.

Mariam Md. Salleh, Mohammed Sani Ibrahim, \& Siti Rahayah Ariffin. (2009). Kepimpinan dan pengurusan strategik di institusi pendidikan MARA. Jurnal Pendidikan Malaysia, 34 (1), 219-233.

Mohamed Elamiri. (2013). Plotting a path towards sustainable air transportation. International Civil Aviation Organization Training Report, 3(1).

Mohd Khalit Othman. (2006). Model pengurusan kualiti bagi perkhidmatan teknologi maklumat: Fokus kepada bahagian perkhidmatan pengguna sektor awam. International Journal of Management Studies, 14 (1), 145-162.

Mohd Zulfadly Othman, Rohana Hamzah, Ismail Sabri Norihan \& Muhammad Afzamiman Aripin. (2011). Dua teras, satu destinasi: Pelan reformasi strategik PTV ke arah pembangunan sejagat. Jurnal Teknologi, 56 (Sains Sosial), Sept. 2011: $101-117$. 


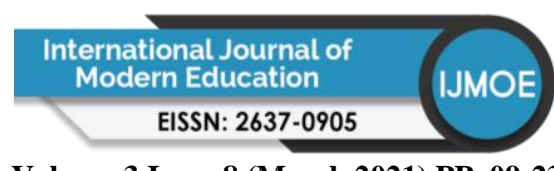

Volume 3 Issue 8 (March 2021) PP. 09-23

DOI: 10.35631/IJMOE.38002

Naidoo, P., Schaap, P., \& Vermeulen, L. P. (2014). The development of a measure to assess perceptions of the advanced aircraft training climate. The International Journal of Aviation Psychology, 24(3), 228 - 245.

Newton, J. (2002). Barriers to effective quality management and leadership: Case study of two academic department. Higher Education, 44, 185 - 212.

Norbahiah Misran, Siti Salasiah Mokri, Hafizah Husain and Wan Mimi Diyana Wan Zaki. (2011). Continual quality improvement process for undergraduate programs. Procedia Social and Behavioral Sciences, 18, 565-574.

Norshah Hafeez Shuaib, Adzly Anuar, Ramesh Singh \& Mohd Zamri Yusoff. (2009). Implementing continual quality improvement (CQI) process in an outcome-based education (OBE) approach. Prosiding dalam The $2^{\text {nd }}$ International Conference of Teaching and Learning (ICTL 2009). INTI University College, Malaysia.

Norshidah Nordin. (2011). The influence of emotional intelligence, leadership behaviour and organizational commitment on organizational readiness for change in higher learning institution. Procedia - Social and Behavioral Sciences, 29. 129 - 138.

O'Mahony, K. \& Garavan, T. N. (2012). Implementing a quality management framework in a higher education organisation: A case study. Quality Assurance in Education, 20(2) $184-200$.

Øvretveit, J. (2005). Leading improvement. Journal of Health Organization and Management, 19(6), 413-430.

Pallant, J. (2013). SPSS survival manual: A step by step guide to data analysis using IBM SPSS (4th ed.). Crows Nest, NSW: Allen \& Unwin.

Pearce, J.A. \& Robinson, R.B. (2007). Formulation, Implementation and Control of Competitive Strategy (9th ed). Boston, MA: McGraw-Hill Irwin.

Pisapia J. (2009). The strategic leader new tactics for a globalizing world. Charlotte, North Carolina: Information Age Publishing.

Rashidah Mokhtar, Nur Huda Jaafar, Safura Adeela Sukiman \& Azizah Abd. Rahman. (2012, October). Continuous quality improvement (CQI) readiness towards Malaysian Quality Assurance (MQA). Proceeding of the International Conference On Management, Economics and Finance (ICMEF), Kuching, Sarawak, Malaysia.

Ronquillo, J. C. (2011). Servant, transformational and transactional leadership. Dalam K. A. Agard (Ed.), Leadership in nonprofit organizations: A reference handbook (345-353). Thousand Oaks, CA: Sage.

Samsuni Mohd. Nor \& Zakaria Abd Hadi. (2005). Perancangan strategik organisasi melalui pelaksanaan balanced scorecard. Jurnal Pengurusan Awam, 4(1), $64-76$.

Santhidran, S. Chandran, V. G. R. \& Borromeo, J. (2013). Enabling organizational change Leadership, commitment to change and the mediating role of change readiness. Journal of Business Economics \& Management, 14(2), 348 - 363.

Schaffernak, H., Mösl, B., Vorraber, W., \& Koglbauer, I. (2020). Potential augmented reality application areas for pilot education: An exploratory study. Education Sciences 10(4), 86. DOI: $10.3390 /$ educsci10040086

Seetharaman, A., Sreenivasan, J., \& Boon, P. L. (2006). Critical success factors of total quality management. Quality \& Quantity, 40, 675-695.

Smith, I. (2005). Achieving readiness for organisational change. Library Management, 26(6/7), $408-412$.

Sokovic, M., Jovanovic, J., Krivokapic, Z \& Vujovic, A. (2009). Basic quality tools in continuous improvement process. Journal of Mechanical Engineering, 55(5), 1 - 9. 


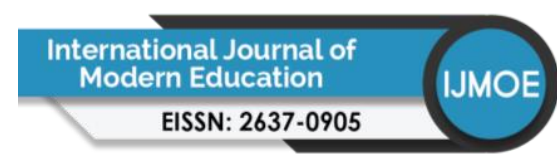

Volume 3 Issue 8 (March 2021) PP. 09-23 DOI: 10.35631/IJMOE.38002

Solomons, N. M. \& Spross, J. A. (2011). Evidence-based practice barriers and facilitators from a continuous quality improvement: an integrative review. Journal of Nursing Management, 19, 109 - 120.

Testani, M. V., \& Sreekanth Ramakrishnan, S. (2012). Lean leadership readiness for change: A methodology for lean change readiness and continuous improvement. Dalam G. Lim and J.W. Herrmann, (Eds), Proceedings of the 2012 Industrial and Systems Engineering Research Conference, May 2012 Orland Florida. Dimuat turun daripada http://www.xcdsystem.com/iie2014/

Vagias, W. M. (2006). Likert-type scale response anchors. Clemson International Institute for Tourism \& Research Development, Department of Parks, Recreation and Tourism Management. Clemson University.

Vera, D. \& Crossan, M. (2004). Strategic leadership and organizational learning. The Academy of Management Review, 29(2), 222 - 240.

Victorian Quality Council. (2006). Better quality, better health care - a safety and quality improvement framework for Victorian health services. Department of Human Services.

Wardhania, V., Utarinib, A., Dijkc, J. P. V., \& Postc, D. (2009). Determinants of quality management systems implementation in hospitals. Health Policy, 89, 239-251.

Yamada, T. T., Poltroniere, C. F., Gambi, L. N. \& Gerolamo, M. C. (2013). Why does the implementation of quality management practices fail? A qualitative study of barriers in Brazilian company. Procedia - Social and Behavioral Sciences, 81, 366 - 370.

Yavuz Akbulut, Abdullah Kuzu, Colin Latchem \& Ferhan Odabasi. (2007). Change readiness among teaching staff at Anadolu University, Turkey. Distance Education, 28(3), 335 350 .

Zoogah, D. B. (2009). Cultural value orientation, personality, and motivational determinants of strategic leadership in Africa. International Journal of Leadership Studies, 4(2), 202 $-222$.

Zuraini Dahari, Umi Kalthum Ngah \& Norizah Mohamad. (2012). Continuous quality improvement (CQI) implementation in electrical \& electronic engineering final year projects. Proceeding of the 4th International Congress on Engineering Education, Penang, Malaysia. 